\title{
GENETIC VARIABILITY FOR GRAIN NUTRIENTS CONTENT IN COASTAL RICE COLLECTIONS OF BANGLADESH
}

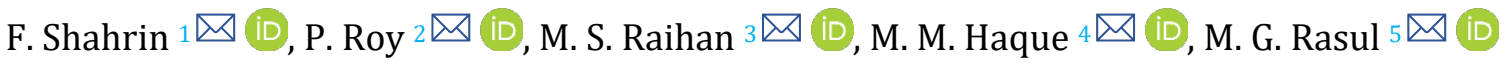 \\ 1,2 M S Student, Department of Genetics and Plant Brededing, Bangabandhu Sheikh Mujibur Rahman \\ Agricultural University (BSMRAU), Gazipur 1706, Bangladesh. \\ 3,5 Professor, Department of Genetics and Plant Breeding, Bangabandhu Sheikh Mujibur Rahman Agricultural \\ University (BSMRAU), Gazipur 1706, Bangladesh. \\ ${ }^{4}$ Professor, Department of Agronomy, Bangabandhu Sheikh Mujibur Rahman Agricultural University \\ (BSMRAU), Gazipur 1706, Bangladesh.
}

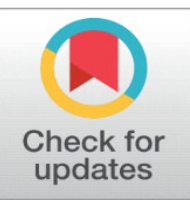

Received 17 October 2021

Accepted 1 November 2021

Published 30 November 2021

\section{CorrespondingAuthor}

M. G. Rasul, mdgolam60@yahoo.com

DOI

10.29121/granthaalayah.v9.i11.2021 4400

Funding: This research received no specific grant from any funding agency in the public, commercial, or not-for-profit sectors.

Copyright: (C) 2021 The Author(s). This is an open access article distributed under the terms of the Creative Commons Attribution License, which permits unrestricted use, distribution, and reproduction in any medium, provided the original author and source are credited.

\section{ABSTRACT}

Overcoming malnutrition through biofortification breeding in rice is aimed to assist nutritional food security in Bangladesh. So, to select parents for nutritional improvement, estimation and exploitation of mineral nutrients reserves of rice grain and their variability assessment in different genotypes is essential. Eighty-five (85) T. aman rice genotypes collected from different coastal regions of Bangladesh were evaluated the Advanced Plant Breeding laboratory, GPB of BSMRAU to estimate the grain nutrients content and to elucidate their genetic variability among the genotypes. Considerable significant variation $(0.1 \%$ level of probability) was noted among the genotypes for studied different grain nutrient contents and yield per hill. The mean values of $\mathrm{N}, \mathrm{P}, \mathrm{K}, \mathrm{Ca}$, $\mathrm{Mg}, \mathrm{Na}, \mathrm{Zn}, \mathrm{Fe}, \mathrm{Cu}, \mathrm{Mn}$ and grain yield/ hill were $10788.24 \mathrm{mg} / \mathrm{kg}, 804.85 \mathrm{mg} / \mathrm{kg}, 3798.58$ $\mathrm{mg} / \mathrm{kg}, 13795.29 \mathrm{mg} / \mathrm{kg}, 2778.87 \mathrm{mg} / \mathrm{kg}, 3771.17 \mathrm{mg} / \mathrm{kg}, 7.25 \mathrm{mg} / \mathrm{kg}, 5.01 \mathrm{mg} / \mathrm{kg}, 1.05$ $\mathrm{mg} / \mathrm{kg}, 1.90 \mathrm{mg} / \mathrm{kg}$ and $433.29 \mathrm{~g}$, respectively. Box and whisker plots analysis were done to represent data graphically for better understanding. Histogram was used to present the frequency distribution of genotypes for $\mathrm{N}, \mathrm{P}, \mathrm{K}, \mathrm{Ca}, \mathrm{Mg}, \mathrm{Na}, \mathrm{Zn}, \mathrm{Fe}, \mathrm{Cu}, \mathrm{Mg}$ and Grain yield/hill content in 85 diverged rice genotypes All the traits had equality in genotypic and phenotypic variances with high heritability and high genetic advance which indicated preponderance of additive gene effects for these traits. The genotype R080 (Chinigura) contained the highest content of grain P, Fe and Cu. The R030 (Mota Dhan), R040 (Dudh Kalam) and R019 (Chikon Dhan) were noted for the highest $\mathrm{Ca}, \mathrm{Mg}$ and $\mathrm{Na}$ content, respectively. The maximum N and Zn content were observed in R029 (Dudh Kolom) and R075 (Gopal Bogh), respectively. R083 (Lal Dhan) was marked for the highest grain yield/ hill and K content. Genetic variability parameters, heat map analysis and neighbor joining clustering methods indicated these genotypes including R079 can be considered for biofortification program and used as parents for the improvement of those grain nutrients in rice breeding.

Keywords: Coastal Rice, Grain Nutrients, Nutrient Deficiency, Boxplot, Biofortification, Heatmap, Neibour Joining

\section{INTRODUCTION}

Rice is the staple food and leading cereal crop of about 135 million people of Bangladesh which is cooked and consumed as whole grain. It provides nearly $48 \%$ of rural employment, about two-third of total calorie supply and about onehalf of the total protein intakes Matin et al. (2017). Bangladesh has a total area of 
14.8 $\mathrm{M}$ ha, out of $2.85 \mathrm{M}$ ha of coastal and off-shore land, about $1 \mathrm{M}$ ha is affected by varying degrees of salinity Anjum and Hossain (2019). In Bangladesh, over 30\% of the net cultivable area exists in the coastal region and usually $30-50 \%$ yield losses occur depending on the level of soil salinity Mamun et al. (2019). The dominant crop grown in the coastal region is local transplanted aman rice crop with low yields. It adversely affects the economy of the country. So, it is very important to screening out the local salt tolerant rice varieties and improves the crop yield and quality in salt affected area Shozib et al. (2017).

Rice quality composed of components such as nutritional aspects, appearance, cooking quality and eating quality is considered as the second most important objective following yield. Rice is known to have high quantity of carbohydrate and high-quality protein (lysine) indicating it as a good source of energy Thongbam et al. (2012). It is relatively low in some essential micronutrients such as iron (Fe), zinc ( $\mathrm{Zn}$ ) and calcium ( $\mathrm{Ca}$ ) as compared to other staple crops like wheat, maize, legumes and tubers Adeyeye et al. (2000). Micronutrient especially Zn, Fe and Cu deficiency is termed as hidden hunger which can affect brain and immune functions Imtiaz et al. (2005). Half of the world's population is suffering from one or more vitamin and/or mineral deficiency World Food Programme (2015). More than three billion people are affected by micronutrient malnutrition and 3.5 million children die each year out of malnutrition Gearing (2015) and the numbers are gradually increasing (FA0, 2009; Johnson et al. (2011). The malnutrition problem is very acute in South Asia including Bangladesh Das and Gulshan (2017).

Above mentioned facts clearly indicate that besides enhancing the growth and yield of rice, enrichment of the grains with nutrients holds immense importance to address more important nutrient malnutrition related global health problem. The developed countries are managing deficiency by adopting biofortification programs. Biofortification is the development of nutrient dense staple food crops using the best conventional breeding practices and modern biotechnology, without sacrificing agronomic performance and important consumer preferred traits. It is an effective and cheaper alternate to traditional ways of combating micronutrient deficiencies Haas et al. (2005). Biofortification of staple food crops for enhanced micronutrient content through genetic manipulation is the best option available to alleviate hidden hunger with little recurring costs Welch and Graham (2004), Graham et al. (2007). Increasing the micronutrient content of grain by biofortification offers great potential to combat micronutrient deficiency and dramatically impact human health Bashir et al. (2013). Earlier investigation has indicated that micronutrient enrichment traits are available within the genomes of major crops; as a result, improvements in micronutrient concentration can be made through biofortification without adversely affecting yield Welch and Graham (2004). Rice is the most amenable crop for molecular genetic studies due to its small genome size, enriched genetic map, availability of entire genome sequence and relative ease of transformation Reddy et al. (2018). For this reason, in rice, it is possible to combine the high micronutrient density trait with high yield economically through biofortification. World Health Organization (WHO) recommended that rice can be fortified by adding a micronutrient powder to the rice that adheres to the grains or spraying of the surface of ordinary rice grains in several layers with a vitamin and mineral mix to form a protective coating. Rice kernels can be fortified with several micronutrients and vitamins Nagesh et al. (2012).

Thus, the present study aimed to determine the grain nutrients content of coastal rice germplasm and also the extent of genetic variability to select superior rice germplasm adapted in coastal areas. Strategically using this diversity, the 
breeder can develop high yielding varieties of rice with improved quality adapted in coastal regions and can biofortify rice with micronutrients aiming to provide all the essential nutrients with the dominant diet rice.

\section{MATERIALS AND METHODS}

\section{Sample preparation}

The experiment was conducted at the Advanced Plant Breeding laboratory of Department of Genetics and Plant Breeding, Bangabandhu Sheikh Mujibur Rahman Agricultural University, Salna, Gazipur. For this purpose, 85 local varieties of T aman paddy were used which were previously collected by the GPB department from coastal regions (Khulna, Bagerhat, Patuakhali, Feni and Cox's Bazar) of Bangladesh. The husk of the paddy was removed by hand and thus the paddy was converted to rice. These rice grains were used as raw sample in different mineral analysis. Then 120 grains of each rice samples were ground to fine powder by using mortar and pestle and preserved in an individual packet until analysis. A minimum of 3 pellets of each sample were made to reduce the error in the analysis.

\section{Parameters for evaluation}

Parameters for nutritional qualities were nitrogen $(\mathrm{mg} / \mathrm{kg})$, phosphorus $(\mathrm{mg} / \mathrm{kg})$, potassium $(\mathrm{mg} / \mathrm{kg})$, calcium $(\mathrm{mg} / \mathrm{kg})$, magnesium $(\mathrm{mg} / \mathrm{kg})$, sodium $(\mathrm{mg} / \mathrm{kg})$, zinc $(\mathrm{mg} / \mathrm{kg})$, iron $(\mathrm{mg} / \mathrm{kg})$, copper $(\mathrm{mg} / \mathrm{kg})$, manganese $(\mathrm{mg} / \mathrm{kg})$ along with grain yield/ hill (g).

\section{Estimation of nitrogen from rice sample by Micro Kjeldahl method}

Micro-kjeldahl method was used for the estimation of total nitrogen in rice grain. Three steps were carried out for the estimation of total Nitrogen content. First step was digestion, powdered rice sample (0.1 gram) was taken in a $75 \mathrm{~mL}$ Kjeldahl flask and five milliliters of concentrated $\mathrm{H}_{2} \mathrm{SO}_{4}, 0.5$ gram of digestion mixture were added. The digestion mixture was made by potassium sulphate $\left(\mathrm{K}_{2} \mathrm{SO}_{4}\right)$, copper sulphate $\left(\mathrm{CuSO}_{4}\right)$ and selenium powder. This mixture act as a catalyst to hasten the digestion by increasing the temperature quickly. The flask was placed on digestion chamber and boiled until the mixture contained became clear. The flask was cooled slowly and the digested sample was diluted to $100 \mathrm{~mL}$ with distilled water. For distillation, 10 milliliters of diluted digested sample were taken and $10 \mathrm{~mL}$ of $40 \%$ $\mathrm{NaOH}$ was poured into the flask slowly holding the flask at about 450 angle and immediately connected to a distillation set. The distillate was collected in a conical flask containing $5 \mathrm{ml}$ of $1 \%$ boric acid solution and 2-3 drops of methyl orange indicator. Collected volume of distillate was $20 \mathrm{ml}$. After that total distillate was titrated with $0.1 \mathrm{~N} \mathrm{HCl}$ and titration value was recorded. Percentage of nitrogen was calculated by the following formula:

$$
\% \text { Nitrogen }=\frac{(T s-T b)^{\times} \text {Normality of Acid } \times 0.014^{\times} 100}{\text { Weight of Sample }(g)}
$$

Where, Ts $=$ Titre value of the sample

$\mathrm{Tb}=$ Titre value of the blank

$0.014=$ Milli equivalent wt. of Nitrogen 


\section{Mn \\ Procedure of digestion for the estimation of $\mathrm{P}, \mathrm{K}, \mathrm{Ca}, \mathrm{Mg}, \mathrm{Na}, \mathrm{Zn}, \mathrm{Fe}, \mathrm{Cu}$ and}

Half gram $(0.5 \mathrm{~g})$ of rice grain powder was taken in $50 \mathrm{ml}$ conical flask and $5 \mathrm{ml}$ of di-acid mixture $\mathrm{HNO}_{3}: \mathrm{HClO}_{4}=2: 1$ was added. It was kept overnight at room temperature and then placed on electric sand bath at a temperature of 1800-2000C for one hour. After a few minutes brown fume evolved which indicated the starting of digestion process. Finally, white fume was seen by clearing the solution. Heating was then stopped and the digested sample was cooled for about 30 minutes. Then about $10-20 \mathrm{ml}$ distilled water was added to each conical flask. The obtained solution was filtered into a $100 \mathrm{ml}$ volumetric flask and the volume was made up to the mark $(100 \mathrm{ml})$ by the addition of distilled water. The solution was then used as working solution.

\section{$\mathrm{P}, \mathrm{K}, \mathrm{Ca}, \mathrm{Mg}, \mathrm{Na}, \mathrm{Zn}, \mathrm{Fe}, \mathrm{Cu}$ and $\mathrm{Mn}$ content determination by Atomic Absorbance Spectrophotometer (AAS)}

The principle involves that the atoms of $\mathrm{P}, \mathrm{K}, \mathrm{Ca}, \mathrm{Mg}, \mathrm{Na}, \mathrm{Zn}, \mathrm{Fe}, \mathrm{Cu}$ and $\mathrm{Mn}$ normally remain in ground state, but under flame condition they absorb energy when subjected to radiation and is proportional to the specific wave length. The absorption of radiation is proportional to the concentration of the element. $\mathrm{P}, \mathrm{K}, \mathrm{Ca}$, $\mathrm{Mg}, \mathrm{Na}, \mathrm{Zn}, \mathrm{Fe}, \mathrm{Cu}$ and $\mathrm{Mn}$ content was estimated by using Atomic Absorbance Spectrophotometer (AAS) at a wavelength of $440 \mathrm{~nm}, 766.5 \mathrm{~nm}, 422.7 \mathrm{~nm}, 589.0$ $\mathrm{nm}, 285.2 \mathrm{~nm}, 213.9 \mathrm{~nm}, 248.33 \mathrm{~nm}, 324.8 \mathrm{~nm}$ and $279.5 \mathrm{~nm}$, respectively.

\section{Statistical Analysis}

All data obtained for each character were subjected to the analysis of variance. Genetic parameters viz. Mean (x), range, standard error (SE), standard deviation (SD), $\mathrm{F}$ test at $1 \%$ and $\mathrm{CV} \%$ for each character were estimated by the formula given by Burton (1952), Burton and Vane (1953) and Johonson and Comostock. (1955) through STAR (IRRI) and Minitab version 17 software. Box and Whisker plot analysis was also done in 85 genotypes per characters as per Tukey (1977). Frequency distribution of 85 genotypes per character was pictorially presented in histogram using Microsoft Excel program. Heatmap relying on pair-wise genetic distance was generated exploiting the software Heatmapper, according to the method described by Babicki et al. (2016) and neighbor joining tree was contructed using DARwin software 6.0

\section{RESULTS AND DISCUSSION}

\section{Mean Performances and General Variability Parameters of 85 Rice Genotypes}

Highly significant variations were observed among the rice genotypes for different grain nutrient content and grain yield/hill studied at $0.1 \%$ level of probability. The finding of the characters is elaborated underneath

1) Nitrogen: Nitrogen is a vital component of the human body which is necessary for cell replacement, tissue repair, protein synthesis and production of new cells. Nitrogen deficient results in Kwashiorkor, marasmus, liver enlargement and other health complications such as long-term mental and physical damage, shock, hypochondria, etc Cousens (2017). 
The study showed that grain nitrogen content among the genotypes varied from 8599 to $14301 \mathrm{mg} / \mathrm{kg}$ with a mean value of $10788.240 \mathrm{mg} / \mathrm{kg}$ (Table 1). The minimum content of nitrogen was observed in nine genotypes viz. R067 (Mou Lota), R069 (Ghecoch Mota), R070 (Kala khora), R078 (Satas IRRI), R081 (Gobindo Bogh), R083 (Lal Dhan), R088 (Kajol Hail), R90 (Kalijira) and R091 (Ghecoch Aman) (8599 mg/kg). Six genotypes viz. R009 (Hogla Pata), R010 (Chini Kanai), R013 (Jota Balam), R017 (Chikon), R022 (Hori Bogh) and R029 (Dudh Kolom) possessed the maximum content of nitrogen $(14301 \mathrm{mg} / \mathrm{kg})$. These data have illustrated in a boxplot (Figure 1). In the boxplot, box edges showed upper and lower quartiles and the median was shown as a bold line in the upper quartile. This trait is negatively skewed.

Histogram bar showed the frequency distribution of 85 rice genotypes for nitrogen content (Figure 2). The highest number of genotypes was 42 which was $49 \%$ of all the genotypes found in the midst of $2^{\text {nd }}$ bin ranged from 10100 to 11600 $\mathrm{mg} / \mathrm{kg}$. None of the genotype was found containing nitrogen ranged from 11600 to $13100 \mathrm{mg} / \mathrm{kg}$. Out of 85 genotypes, 12 genotypes showed above average mean performance. The coefficient of variation (CV) for nitrogen was $1.78 \%$ with standard deviation of 192.77 (Table 1). Souci et al. (1986) and Eggum (1969), Eggum (1977) Eggum (1979) observed the nitrogen content of brown rice as $11680 \mathrm{mg} / \mathrm{kg}$. This result was in close agreement with our findings where nitrogen content varies from 8599 to $14301 \mathrm{mg} / \mathrm{kg}$.

2) Phosphorus (mg/kg): Phosphorus is a mineral found in the bones and processed by the kidneys. The mineral also exists in smaller amounts in cells and other tissues for growth and repair. Metabolic bone disease of prematurity is caused by deficiencies in dietary phosphate and calcium Chinoy et al. (2019).

Grain phosphorus content among the rice genotypes varying from 66.42 to $1862.9 \mathrm{mg} / \mathrm{kg}$ with a mean value of $804.85 \mathrm{mg} / \mathrm{kg}$ was revealed in this study. The minimum content of phosphorus was $66.42 \mathrm{mg} / \mathrm{kg}$ observed in the genotype, R020 (Chapshail). The maximum content of phosphorus was $1862.9 \mathrm{mg} / \mathrm{kg}$ found in R080 (Chinigura). These data are graphically represented in a boxplot (Figure 1). In the boxplot, box edges showed upper and lower quartiles and the median as shown in the middle of box. Individual falling outside of the rank of whisker as outlier is shown as circle. This trait is fitted with normal distribution.

Frequency distribution regarding phosphorus content of 85 rice genotypes illustrated in Histogram bar (Figure 2) revealed that the highest number of genotypes was 31 ( $37 \%$ of all the genotypes) found in the midst of $2^{\text {nd }}$ bin ranged from 366.42 to $666.42 \mathrm{mg} / \mathrm{kg}$. Importantly, only a single genotype (R080) was found containing phosphorus ranged from 1566.42 to $1866.42 \mathrm{mg} / \mathrm{kg}$. 25 rice genotypes among 85 genotypes exhibited above average mean performance. The coefficient of variation (CV) for phosphorus was $4.639 \%$ with standard deviation of 37.488 (Table 1).

Agarwal et al. (2012a) observed concentrations of phosphorus was 330 $\pm 81 \mathrm{mg}$ $100 \mathrm{~g}^{-1}$ in rice grains. Zeng et al. (2004) quantified 653 unpolished Yunnan rice samples. They found average value of P content in core collection of Yunnan rice reached to $3812.56 \mathrm{mg} / \mathrm{kg}$ in the core collection of rice. In the present study, our mean grain phosphorus was $804.85 \mathrm{mg} / \mathrm{kg}$. Some distinct differences observed between our findings and the other researcher's findings mentioned earlier because of the different genetic materials used in the experiments and alternate methods used to obtain data. 
3) Potassium ( $\mathrm{mg} / \mathrm{kg})$ : Potassium is an important mineral needed by the body for normal metabolism, cell, tissue and organ function, muscle growth, and normal activity of the heart Chaudhari et al. (2018).

Nonetheless, potassium content in rice grain of the corresponding genotypes ranged from 2030 to $6079 \mathrm{mg} / \mathrm{kg}$ with a mean value of $3798.58 \mathrm{mg} / \mathrm{kg}$ where the minimum content of potassium was $2030 \mathrm{mg} / \mathrm{kg}$ revealed in R033 (Sada Mota) and R059 (Dinga Moni). Moreover, the genotype R083 (Lal Dhan) exhibited the maximum amount of potassium as $6079 \mathrm{mg} / \mathrm{kg}$. Boxplot (Figure 1) displaying the dataset of potassium content where box edges showed upper and lower quartiles as well as the median in the middle of box signifying that this trait is fitted with normal distribution.

Histogram displaying the frequency distribution of 85 rice genotypes for potassium content (Figure 2) disclosed that the $1^{\text {st }}$ bin ranged from 2030 to 2920 $\mathrm{mg} / \mathrm{kg}$ included the highest number of rice genotypes that was 25 (29\%) among 85 genotypes. Forty genotypes among 85 genotypes exhibited above average mean performance. Besides this information, it was also exposed that 40 genotypes from the 85 considered coastal rice germplasm performed above average mean performance for grain potassium content and coefficient of variation (CV) for potassium was $2.938 \%$ with standard deviation of 112.054 (Table 1 ).

Such finding is supported by Zeng et al. (2004) who quantified of 653 unpolished Yunnan rice samples and found average value of K content (2673.22 $\mathrm{mg} / \mathrm{kg}$ ) in the core collection of rice. However, Agarwal et al. (2012a) reported high concentrations of potassium $\left(2153 \pm 27.81 \mathrm{mg} 100 \mathrm{~g}^{-1}\right)$ in rice grains. Muhammad et al. (2012) quantified 2378 to $2794 \mathrm{mg} \mathrm{kg}^{-1}$ potassium in rice.

4) Calcium (mg/kg) Calcium helps human body to develop strong bones and teeth. Calcium deficiency can lead to bone loss, convulsions and abnormal heart rhythms Khan and Gotter (2018).

The study exposed that calcium content in rice grain of different genotypes ranged from 2801 to $39200 \mathrm{mg} / \mathrm{kg}$ with a mean value of $13,795.290 \mathrm{mg} / \mathrm{kg}$. The minimum content of calcium was $2801 \mathrm{mg} / \mathrm{kg}$ observed in R065 (Kala Kora). The maximum content of calcium was $39200 \mathrm{mg} / \mathrm{kg}$ found in R030 (Mota Dhan). These data are illustrated in a boxplot (Figure 4). In the boxplot, box edges showed upper and lower quartiles and the median as shown in the middle of box. This trait is negatively skewed.

Histogram explored the frequency distribution of 85 rice genotypes for calcium content (Fig. 15). The $1^{\text {st }}$ bin ranged from 2800 to $10200 \mathrm{mg} / \mathrm{kg}$ included the highest number of rice genotypes that was $40(47 \%)$ among 85 genotypes. Out of 85 genotypes, 26 genotypes displayed above average mean performance. The coefficient of variation (CV) for calcium was $6.755 \%$ with standard deviation of 935.60 (Table 1).

Mbatchou and Dawda (2013) observed $95.86 \pm 29.39 \mathrm{mg} \mathrm{kg}^{-1}$ calcium in rice grain. Agarwal et al. (2012a) observed high concentrations of calcium (13.12 \pm 2.66 mg $100 \mathrm{~g}^{-1}$ ) in rice grains. Muhammad et al. (2012) quantified 825 to $1330 \mathrm{mg} \mathrm{kg}^{-1}$ calcium in rice grain. Zeng et al. (2004) quantified of 653 unpolished Yunnan rice samples. They found average value of Ca content was $263.72 \mathrm{mg} / \mathrm{kg}$ in the core collection of rice. The studied materials had grain calcium content in different rice genotypes varied from 2801 to $39200 \mathrm{mg} / \mathrm{kg}$. 


\begin{tabular}{|c|c|c|c|c|c|c|c|}
\hline \multirow[t]{2}{*}{ Traits } & \multirow[t]{2}{*}{ Mean } & \multicolumn{2}{|l|}{ Range } & \multirow[t]{2}{*}{$\begin{array}{l}\text { Standard } \\
\text { Deviation }\end{array}$} & \multirow[t]{2}{*}{$\begin{array}{c}\text { CV } \\
(\%)\end{array}$} & \multirow[t]{2}{*}{$\begin{array}{c}\text { Standard } \\
\text { Error }\end{array}$} & \multirow[t]{2}{*}{$\begin{array}{c}\text { F } \\
\text { Test }\end{array}$} \\
\hline & & Min & Max & & & & \\
\hline N(mg/kg) & $10,788.24$ & 8599 & 14301 & 192.77 & 1.78 & 209.08 & $* * *$ \\
\hline$P(\mathrm{mg} / \mathrm{kg})$ & 804.85 & 66.42 & 1862.9 & 37.48 & 4.639 & 40.66 & $* * *$ \\
\hline K(mg/kg) & $3,798.58$ & 2030 & 6079 & 112.05 & 2.938 & 121.54 & $* * *$ \\
\hline $\mathrm{Ca}(\mathrm{mg} / \mathrm{kg})$ & $13,795.29$ & 2801 & 39200 & 935.6 & 6.755 & $1,014.80$ & $* * *$ \\
\hline$M g(m g / k g)$ & $2,778.87$ & 1872 & 4464 & 43.57 & 1.562 & 47.263 & $* * *$ \\
\hline $\mathrm{Na}(\mathrm{mg} / \mathrm{kg})$ & $3,771.17$ & 1950 & 6599 & 104.66 & 2.764 & 113.521 & $* * *$ \\
\hline $\mathrm{Zn}(\mathrm{mg} / \mathrm{kg})$ & 7.2545 & 1.679 & 19.601 & 0.3734 & 5.127 & 0.405 & $* * *$ \\
\hline $\mathrm{Fe}(\mathrm{mg} / \mathrm{kg})$ & 5.011 & 2.201 & 9.5 & 0.2234 & 4.441 & 0.242 & $* * *$ \\
\hline $\mathrm{Cu}(\mathrm{mg} / \mathrm{kg})$ & 1.0588 & 0.21 & 3.99 & 0.0651 & 6.132 & 0.07 & $* * *$ \\
\hline$M n(m g / k g)$ & 1.903 & 0.77 & 4.4 & 0.0582 & 3.046 & 0.063 & $* * *$ \\
\hline GY/ hill (g) & 433.29 & 219.5 & 707.17 & 91.942 & 21.1 & 9.97 & $* * *$ \\
\hline
\end{tabular}

N: Nitrogen, P: Phosphorus, K: Potassium, Ca: Calcium, Mg: Magnesium, Na: Sodium, Zn: Zinc, Fe: Iron, $\mathrm{Cu}$ : Copper, Mn: Manganese, mg/kg: milligram per kg, gy: Grain yield (g).

***significant at $0.1 \%$ level of probability

5) Magnesium (mg/kg): Proper function of muscles and nerves, brain function, energy metabolism, and protein production are controlled by magnesium. Certain medications and chronic health conditions like alcoholism may cause magnesium deficiency Radcliffe (2016).

The grain magnesium content for the genotypes was varied from 1872 to 4464 $\mathrm{mg} / \mathrm{kg}$ with a mean value of $2,778.871 \mathrm{mg} / \mathrm{kg}$ in this study. The minimum content of magnesium was $1872 \mathrm{mg} / \mathrm{kg}$ observed in R054 (Chinigura) whereas the maximum content was $4464 \mathrm{mg} / \mathrm{kg}$ found in R040 (Dudh Kalam). These data are graphically represented in a boxplot (Figure 1). In the boxplot, box edges showed upper and lower quartiles and the median as shown in the middle of box. Individual falling outside of the rank of whisker as outlier is shown as circle. This trait is fitted with normal distribution.

Histogram explained the frequency distribution of 85 rice genotypes for magnesium content (Figure 2). The highest number of genotypes was 29 (34\%) found in the midst of $3^{\text {rd }}$ bin ranged from 2572 to $2922 \mathrm{mg} / \mathrm{kg}$ followed by 24 genotypes (28\%) in the $4^{\text {th }}$ bin. Only a single genotype (R040) was found containing magnesium ranged from 4322 to $4672 \mathrm{mg} / \mathrm{kg}$. But none of the genotype was found between 3972 and $4322 \mathrm{mg} / \mathrm{kg}$ range of magnesium content. 31 genotypes performed above average mean performance from those 85 genotypes. The coefficient of variation (CV) for magnesium was $1.562 \%$ with standard deviation of 43.57 (Table 1).

Mbatchou and Dawda (2013) observed 555.09 $\pm 207.69 \mathrm{mg} \mathrm{kg}^{-1}$ magnesium in rice grain. Agarwal et al. (2012a) observed high concentrations of magnesium

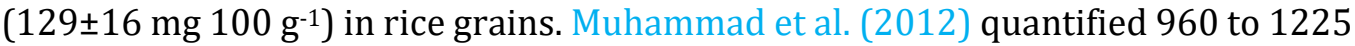
$\mathrm{mg} \mathrm{kg}^{-1}$ magnesium in rice grain. Zeng et al. (2004) quantified of 653 unpolished Yunnan rice samples. They found average value of $\mathrm{Mg}$ content was of $1549.08 \mathrm{mg} / \mathrm{kg}$ in the core collection of rice. 

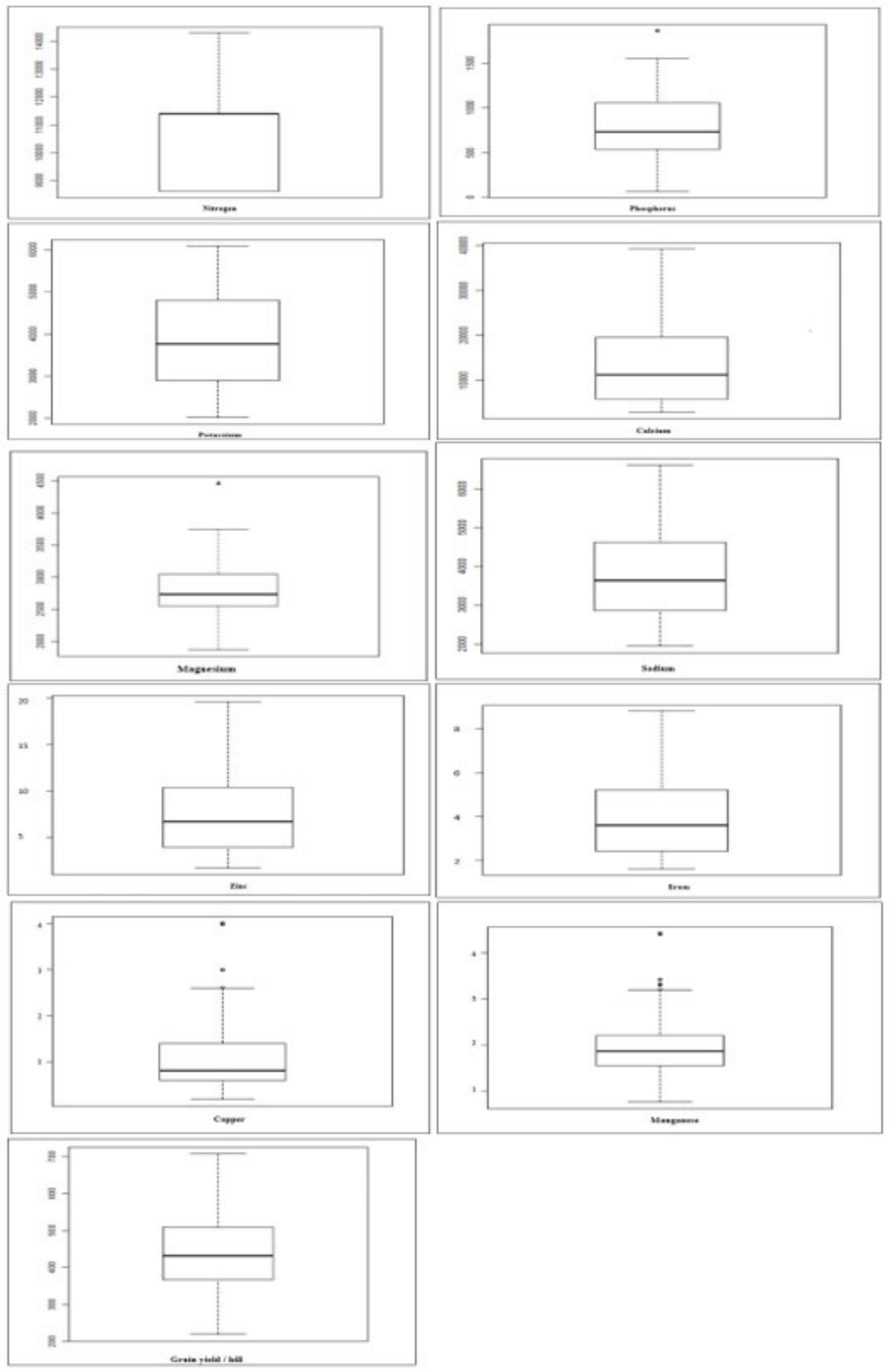

Figure 1 Boxplot showing lower and upper quartiles with median of $\mathrm{N}, \mathrm{P}, \mathrm{K}, \mathrm{Ca}, \mathrm{Mg}, \mathrm{Na}, \mathrm{Zn}, \mathrm{Fe}, \mathrm{Cu}$, $\mathrm{Mg}$ and Grain yield/hill content in 85 diverse rice genotypes 

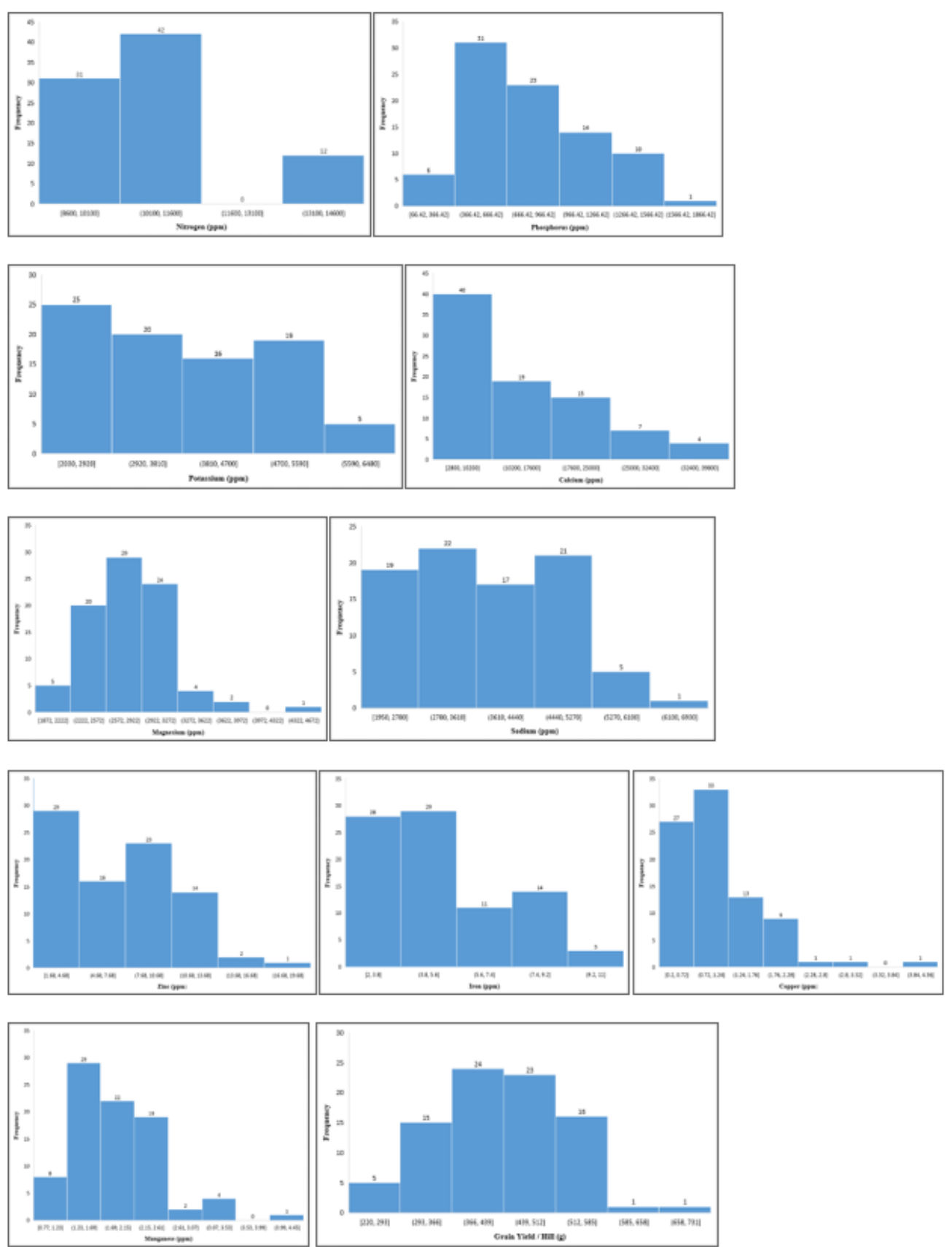

Figure 2 Histogram bar for frequency distribution of genotypes for $\mathrm{N}, \mathrm{P}, \mathrm{K}, \mathrm{Ca}, \mathrm{Mg}, \mathrm{Na}, \mathrm{Zn}, \mathrm{Fe}, \mathrm{Cu}, \mathrm{Mg}$ and Grain yield/hill content in 85 diverse rice genotypes

6) Sodium (mg/kg): Sodium helps maintain normal blood pressure, supports the work of your nerves and muscles, and regulates your body's fluid balance. Hyponatremia occurs when the concentration of sodium in your blood is abnormally low Martel (2017).

Nonetheless, sodium content in rice grain of the corresponding genotypes ranged from from 1950 to $6599 \mathrm{mg} / \mathrm{kg}$ with a mean value of $3,771.177 \mathrm{mg} / \mathrm{kg}$ where the minimum content of sodium was $1950 \mathrm{mg} / \mathrm{kg}$ revealed in R039 (Whitish Dudh Kalam). Moreover, the genotype R019 (Chikon Dhan) exhibited the maximum amount of potassium as $6599 \mathrm{mg} / \mathrm{kg}$. Boxplot (Figure 1) displaying the dataset of 
sodium content where box edges showed upper and lower quartiles as well as the median in the middle of box signifying that this trait is slightly negatively skewed.

Histogram illustrated the frequency distribution of 85 rice genotypes for sodium content (Figure 2). The highest number of genotypes was 22 (26\%) found in the midst of $2^{\text {nd }}$ bin ranged from 2780 to $3610 \mathrm{mg} / \mathrm{kg}$. Only a single genotype (R019) was found containing sodium ranged from 6100 to $6930 \mathrm{mg} / \mathrm{kg}$. Besides above information, it was also exposed that 27 genotypes from the 85 considered coastal rice germplasm performed above average mean performance for grain sodium content. The coefficient of variation (CV) for sodium was $2.764 \%$ with standard deviation of 104.6616 (Table 2).

Such finding is supported by Mbatchou and Dawda (2013) who quantified $60.20 \pm 32.96 \mathrm{mg} \mathrm{kg}^{-1}$ sodium in rice grain. However, Muhammad et al. (2012) quantified 89 to $109 \mathrm{mg} \mathrm{kg}^{-1}$ sodium in rice.

7) Zinc (mg/kg): Zinc is needed by the human body for enzymatic processes. If zinc is deficient, symptoms such as diarrhoea, weight loss and infection appear. Zn deficiency causes growth retardation, hypogonadism, immune dysfunction, and cognitive impairment Prasad (2009).

The zinc content in rice grain of different genotypes ranging from 1.679 to $19.601 \mathrm{mg} / \mathrm{kg}$ with a mean value of $7.254 \mathrm{mg} / \mathrm{kg}$ was revealed in this study where the minimum content of zinc was $1.679 \mathrm{mg} / \mathrm{kg}$ observed in R011 (Benapol) and R013 (Basmati). The maximum content of zinc was $19.601 \mathrm{mg} / \mathrm{kg}$ found in R075 (Gopal Bogh). These data are graphically exemplified in a boxplot (Figure 1). In the boxplot, box edges showed upper and lower quartiles and the median as shown in the middle of box. This trait is negatively skewed.

Histogram presented the frequency distribution of 85 rice genotypes for zinc content (Figure 2). The $1^{\text {st }}$ bin ranged from 1.68 to $4.68 \mathrm{mg} / \mathrm{kg}$ included the highest number of genotypes that was 29 among 85 genotypes which was $34 \%$ of all the genotypes. Only a single genotype (R075) was found containing zinc ranged from 16.68 to $19.68 \mathrm{mg} / \mathrm{kg}$. Out of 85 genotypes, 40 genotypes exhibited above average mean performance. The coefficient of variation (CV) for zinc was $5.12 \%$ with standard deviation of 0.3734436 (Table 2).

Anjum and Hossain (2019) observed zinc content ranged from 24.52 to 32.34 $\mathrm{mg} / \mathrm{kg}$ in some coastal rice varieties in Noakhali region of Bangladesh. Indian Institute of Rice Research, Hyderabad has developed a genotype (IET 23832) that possesses high Zn (19.50 mg/kg) Mahender et al. (2016). Mbatchou and Dawda (2013) observed $10.89 \pm 0.96 \mathrm{mg} \mathrm{kg}^{-1}$ zinc in rice grain. Ravindra (2013) found that zinc concentration was $10-33 \mathrm{mg} / \mathrm{kg}$ in rice. Muhammad et al. (2012) quantified zinc 191 to $319 \mathrm{mg} \mathrm{kg}^{-1}$ in rice. Depar et al. (2011) observed Zn ranged 12.5 to 26.3 $\mathrm{mg} \mathrm{kg}^{-1}$ and 0.12 to $0.59 \mu \mathrm{g} \mathrm{kg}^{-1}$ in rice. Martinez et al. (2010) found that brown rice had $20-25 \mathrm{mg} / \mathrm{kg}$ zinc while milled rice had $16-17 \mathrm{mg} / \mathrm{kg}$ zinc. Suzuki et al. (1980) observed 18.17-3.13 mg/kg Zn in rice. Zeng et al. (2004) quantified of 653 unpolished Yunnan rice samples. They found average value of $\mathrm{Zn}$ contents was of $34.72 \mathrm{mg} / \mathrm{kg}$ in the core collection of rice. In the present study, zinc content in rice grain varied from 1.679 to $19.601 \mathrm{mg} / \mathrm{kg}$. This obtained data was in close agreement with those findings reported earlier in esteemed journals.

8) Iron (mg/kg): Iron is needed by the human body for haemoglobin production. Iron deficiency can be detrimental to health, leading to anemia 
with symptoms of brittle hair, brittle fingernails and fatigue Ahuja et al. (2008), Chaudhari et al. (2018).

The study disclosed that grain iron content among the genotypes varied from 2.201 to $9.5 \mathrm{mg} / \mathrm{kg}$ with a mean value of $5.011765 \mathrm{mg} / \mathrm{kg}$. The minimum content of iron was $2.201 \mathrm{mg} / \mathrm{kg}$ observed in R013 (Basmati), R031 (Montessor), R043 (Boyar Bogh), R054 (Chinigura), R078 (Satas IRRI), R083 (Lal Dhan) and R089 (Kajol Hail). The maximum content of iron was $9.5 \mathrm{mg} / \mathrm{kg}$ found in R023 (Bolenga Dhan), R039 (Whitish Dudh Kalam) and R080 (Chinigura). These data are illuminated in a boxplot (Fig. 8). In the boxplot, box edges showed upper and lower quartiles and the median as shown in the middle of box. This trait is negatively skewed.

Histogram revealed the highest number of genotypes was 29 (34\%) found in the midst of $2^{\text {nd }}$ bin ranged from 3.8 to $5.6 \mathrm{mg} / \mathrm{kg}$ (Figure 2). Only three genotypes (R023, R039 and R080) which was only 4\% of all the genotypes were found containing iron ranged from 9.2 to $11.0 \mathrm{mg} / \mathrm{kg}$. 28 genotypes performed above average mean performance among 85 genotypes. The coefficient of variation (CV) for iron was $4.441 \%$ with standard deviation of 0.223405 (Table 2). Anjum and Hossain (2019) observed iron content ranged from 7.09 to $9.84 \mathrm{mg} / \mathrm{kg}$ in some coastal rice varieties in Noakhali region of Bangladesh. Ravindra (2013) found that iron concentration was 2-34 mg/kg in rice. Mbatchou and Dawda (2013) observed $18.17 \pm 2.86 \mathrm{mg} \mathrm{kg}^{-1}$ iron in rice grain. Agarwal et al. (2012a) observed grain iron

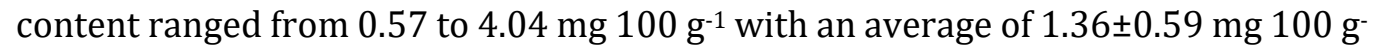
1. Muhammadet al. (2012) quantified iron 186 to $317 \mathrm{mg} \mathrm{kg}^{-1}$ in rice. Depar et al. (2011) observed iron concentrations ranged from 31.6 to $65.0 \mu \mathrm{g} \mathrm{g}^{-1}$ in rice grain. Martinez et al. (2010) found that brown rice had $10-11 \mathrm{mg} / \mathrm{kg}$ iron while milled rice had 2-3 mg/kg iron. Zeng et al. (2004) quantified of 653 unpolished Yunnan rice samples. They found the average value of Fe content was $49.87 \mathrm{mg} / \mathrm{kg}$ in the core collection of rice. These results agree with our findings where iron content varies from 2.201 to $9.5 \mathrm{mg} / \mathrm{kg}$.

9) Copper (mg/kg): Copper, a trace element, is heavily involved in cell oxidation and signaling systems. It helps maintain a healthy metabolism, promotes strong and healthy bones and ensures your nervous system works properly. Copper deficiency may cause iron deficiency anemia Wazir and Ghobrial (2017).

Nonetheless, copper content in rice grain of the corresponding genotypes ranged from from 0.21 to $3.99 \mathrm{mg} / \mathrm{kg}$ with a mean value of $1.058824 \mathrm{mg} / \mathrm{kg}$ where the minimum copper content was observed in R017 (Chikon Dhan), R019 (Chikon Dhan) and R029 (Dudh Kolom) (0.21 mg/kg). Moreover, the genotype, R080 (Chinigura) exhibited the maximum amount of copper as $3.99 \mathrm{mg} / \mathrm{kg}$. Boxplot (Figure 1) displaying the dataset of copper content where box edges showed upper and lower quartiles as well as the median in the middle of box signifying that this trait is slightly negatively skewed.

Histogram explored the highest number of genotypes was 33 (39\%) found in the midst of $2^{\text {nd }}$ bin ranged from 0.72 to $1.24 \mathrm{mg} / \mathrm{kg}$. There was a single genotype in 5th and 6th bin each (R037 and R032, respectively). None of the genotype was found containing copper ranged from 3.32 to $3.84 \mathrm{mg} / \mathrm{kg}$. However, only a single genotype (R080) was found containing copper ranged from 3.84 to $4.36 \mathrm{mg} / \mathrm{kg}$. Besides above information, it was also exposed that 25 genotypes from the 85 considered coastal rice germplasm performed above average mean performance for grain copper content. The coefficient of variation (CV) for copper was $6.132 \%$ with standard deviation of 0.0651 (Table 1). 
Mbatchou and Dawda (2013) observed 26.69 $\pm 9.18 \mathrm{mg} \mathrm{kg}^{-1}$ copper in rice grain. Depar et al. (2011) observed Cu concentrations ranged from 5.90 to $14.3 \mu \mathrm{g} \mathrm{g}^{-1}$ in rice grain. Anjum et al. (2007) found that Irri-9 had $920 \mathrm{mg} / \mathrm{kg}$ copper. Zeng et al. (2004) quantified of 653 unpolished Yunnan rice samples. They found average value of $\mathrm{Cu}$ contents was $15.53 \mathrm{mg} / \mathrm{kg}$ in the core collection of rice. Suzuki et al. (1980) observed $1.11-2.93 \mathrm{mg} / \mathrm{kg} \mathrm{Cu}$ in rice. In this study, copper content in rice grain ranged from 0.21 to $3.99 \mathrm{mg} / \mathrm{kg}$ which was pretty similar with the referred findings.

10) Manganese (mg/kg): Manganese deficiency include impaired growth, impaired reproductive function and skeletal abnormalities. Manganese is also needed for normal functioning of the brain and nerves Ahuja et al. (2008).

The study presented that manganese content in rice grain of different genotypes ranged from 0.77 to $4.4 \mathrm{mg} / \mathrm{kg}$ with a mean value of $1.9036 \mathrm{mg} / \mathrm{kg}$. The minimum content of manganese was $0.77 \mathrm{mg} / \mathrm{kg}$ observed in R041 (Hobori Maloti). The maximum content of manganese was $4.4 \mathrm{mg} / \mathrm{kg}$ found in R095 (Belta Dhan). These data are illustrated in a boxplot (Figure 1) where box edges showed upper and lower quartiles and the median as shown in the middle of box. Individuals falling outside of the rank of whisker as outliers are shown as circles. This trait was fitted with normal distribution.

Histogram illustrated the highest number of genotypes was 29 (34\%) found in the midst of $2^{\text {nd }}$ bin ranged from 1.23 to $1.69 \mathrm{mg} / \mathrm{kg}$ followed by 22 genotypes (26\%) in the 3rd bin. None of the genotype was found containing manganese ranged from 3.53 to $3.99 \mathrm{mg} / \mathrm{kg}$. However, only a single genotype (R095) was found containing manganese ranged from 3.99 to $4.45 \mathrm{mg} / \mathrm{kg}$. Out of 85 genotypes, 26 genotypes exhibited above average mean performance. The coefficient of variation (CV) for manganese was $3.046 \%$ with standard deviation of 0.058207 (Table 2).

Mbatchou and Dawda (2013) observed 2.89 $\pm 0.74 \mathrm{mg} \mathrm{kg}^{-1}$ manganese in rice grain. Depar et al. (2011) observed Mn concentrations ranged from 34.8 to $64.2 \mu \mathrm{g}$ $\mathrm{g}^{-1}$ in rice grain. Anjum et al. (2007) found that rice variety of Dr- 83 had $330 \mathrm{mg} / \mathrm{kg}$ manganese. Zeng et al. (2004) quantified of 653 unpolished Yunnan rice samples. They found the prevailing average value of Mn contents was $15.19 \mathrm{mg} / \mathrm{kg}$ in the core collection of rice. The distinct differences observed between the findings of our study and the other researcher's mentioned findings because of the different genetic materials used in the experiments, variation in climate and soil of experimental sites and different methods used to obtain data. All these factors are constantly responsible for arising variation in each and every experimental data.

11) Grain Yield / hill (g): Grain yield/ hill of the 85 rice genotypes ranged from 219.5.to 707.17 $\mathrm{g}$ with a mean value of $433.294 \mathrm{~g}$ where the lowest grain yield/ hill was observed in R023 (Bolenga Dhan) which was $219.5 \mathrm{~g}$ and the highest grain yield/ hill was found in R083 (Lal Dhan) as 707.17 g. The statistical pattern of the grain yield data has graphically presented in the boxplot (Figure 1) where box edges showed upper as well as lower quartiles and the median as shown in the middle of box revealing that the trait grain yield/ hill was under normal distribution.

Frequency distribution regarding grain yield/ hill (g) of 85 rice genotypes illustrated in Histogram bar (Figure 2) revealed that the highest number of genotypes was 24 (28\%) found in the midst of 3rd bin ranged from 366 to $439 \mathrm{~g}$ followed by 23 genotypes $(27 \%)$ in the 4 th bin. Only a single genotype was found in the midst of each 6th and 7th bin (R055 and R083, respectively) ranged from 585 to 
$658 \mathrm{~g}$ and 658 to $731 \mathrm{~g}$, respectively. As observed for few other traits, 41 genotypes beyond 85 diversed germplasm also explored above average mean performance for grain yield/ hill, simultaneously yielding coefficient of variation (CV) as $21.10 \%$ couple with standard deviation of 91.94 (Table 1).

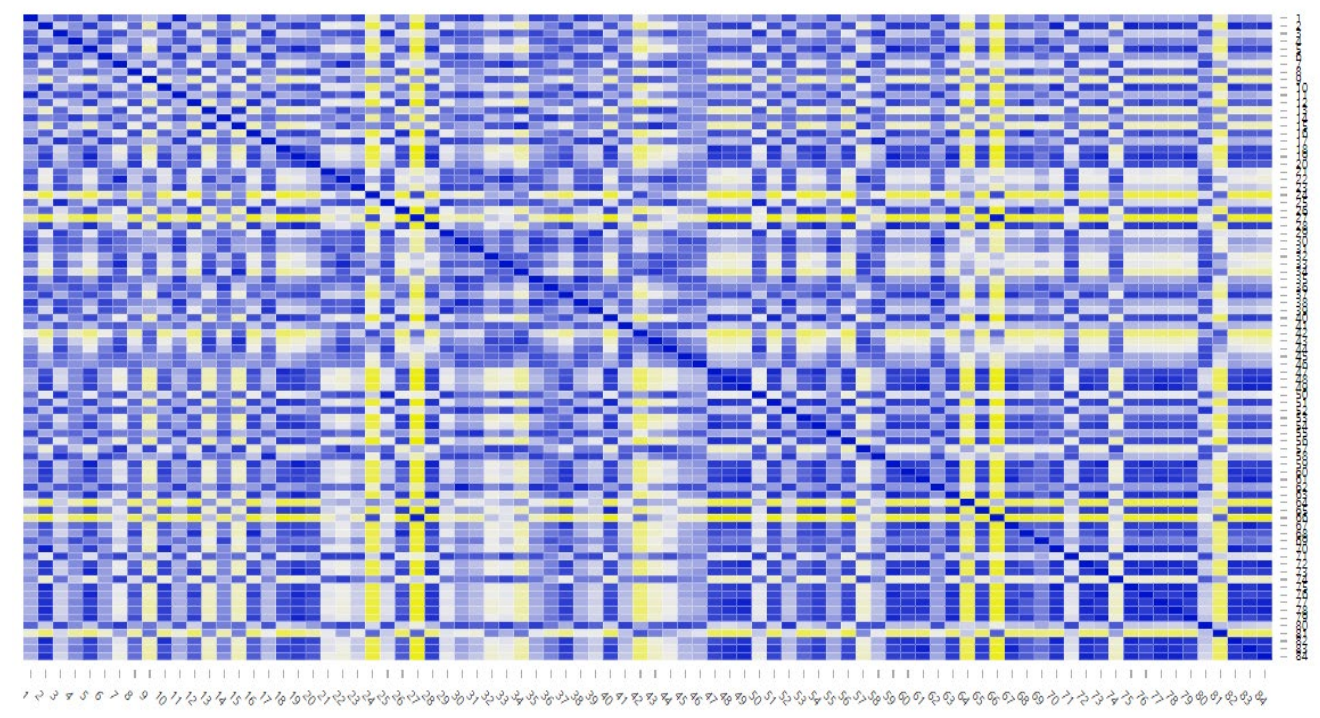

Figure 3 Heat map relying on distance matrix for mean values of eleven nutrient related trait underlying 85 diverged accessions used in the experiment

The heat map (Figure 3) relying on distance matrix of the mean values revealed the genetic variability information of the individuals, with the color richness being related to the delagancy of explaining diverge phenotype. Analysis of the results reconnoitered that the genotypes R024 (Kalijira), R027 (Beti Chikon), R042 (Shakor Khora), R064 (Kajol Sail), R066 (Bouhari) and R081 (Gobindo Bhog) had monotone color signifying relatively highest level of variability than others members considering the entire population. Nonetheless, in addition with above, homogeneous and heterogeneous phenotype for the individuals were also clearly and intuitively expressed in the heat map.

\section{Phenotypic and genotypic variance, heritability and genetic advance of 85 rice genotypes}

In the present investigation, the highest phenotypic and genotypic variance were found for calcium followed by nitrogen, potassium and sodium. Moderate genotypic and phenotypic variances were obtained from magnesium, phosphorus and grain yield/ hill (8307.48 g). The lowest magnitude of phenotypic and genotypic variance was observed for manganese and followed by copper, iron and zinc (Supplement Table 2). The highest phenotypic coefficients of variation and genotypic co-efficient of variation were recorded for calcium $(66.55 \mathrm{mg} / \mathrm{kg})$ followed by copper $(62.13 \mathrm{mg} / \mathrm{kg})$, zinc $(51.48 \mathrm{mg} / \mathrm{kg})$, phosphorus $(46.38 \mathrm{mg} / \mathrm{kg})$ and iron $(45.30 \mathrm{mg} / \mathrm{kg}$ ) (Figure 3 ). No difference was found between the PCV and GCV in all the nutrient traits denoted there is no environmental influence among the genotypes (Figure 3). Thus, selection could be considered by these traits as they are highly heritable. The GCV and PCV were the lowest for magnesium $(15.77 \mathrm{mg} / \mathrm{kg})$, nitrogen $(17.86 \mathrm{mg} / \mathrm{kg})$, sodium $(27.57 \mathrm{mg} / \mathrm{kg})$, potassium $(29.13 \mathrm{mg} / \mathrm{kg})$ and manganese $(30.58 \mathrm{mg} / \mathrm{kg})$. 
All the traits except grain yield had equality in genotypic and phenotypic variances which indicated preponderance of additive gene effects for these traits i.e., almost no or little environmental influence in the expression of these traits or the major portion of the phenotypic variance was genetic in nature and greater scope of improvement of these rice genotypes through selection. Because of this genetic nature of the traits, suitable parents' selection based on these traits will become more effective and less complicated for biofortification program in rice breeding. As there is no environmental influence, so further research on rice grain nutrients qualities improvement based on $\mathrm{Ca}, \mathrm{Cu}, \mathrm{Zn}, \mathrm{P}$ and Fe nutrients can be taken into consideration.

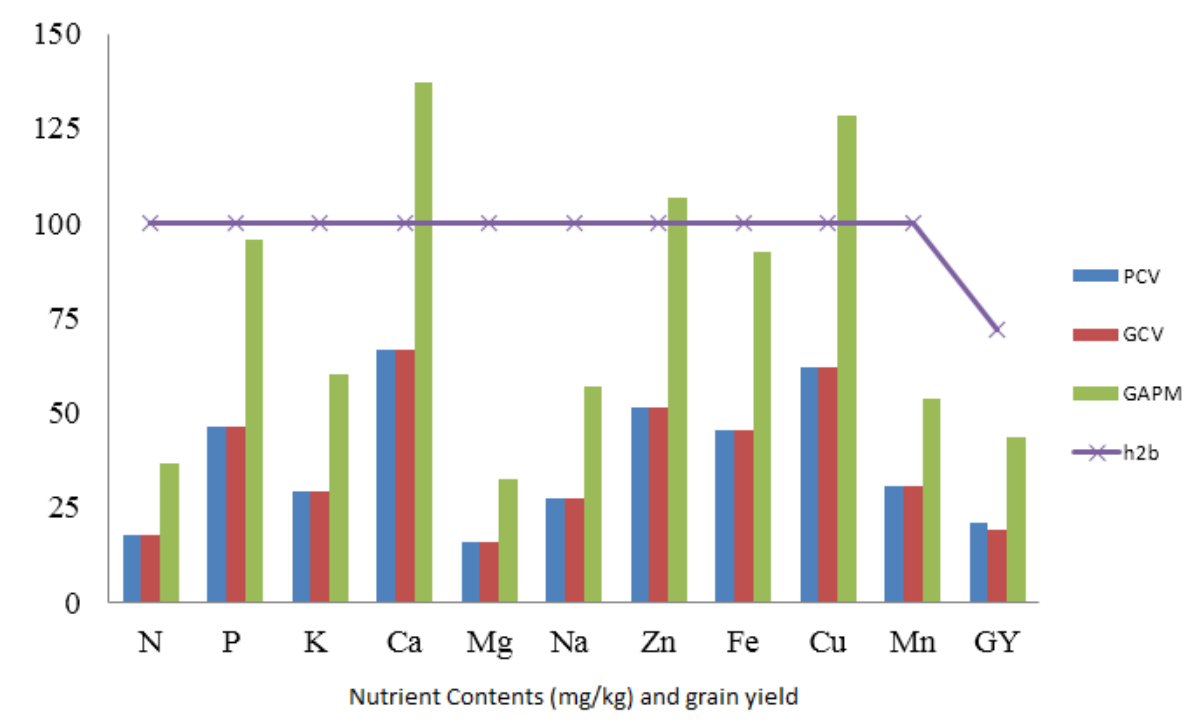

Figure 4 Graphical representation of genetic parameters for 11 traits in 85 rice accessions

In this study, high heritability (100\%) was recorded in all the traits except grain yield/ hill. Seventy two percent (72\%) heritability was noted for grain yield/ hill. These results denoted the additive gene action in the inheritance of these traits. High genetic advance (18940.3) and genetic advance (137.30\%) as percent of mean with $100 \%$ heritability was recorded for grain calcium content which indicated additive gene action is predominant for controlling this character (Figure 4). Low genetic advance (1.0218 and 1.3570) among the eleven traits were found for manganese and copper content while low genetic advance $(32.54 \%$ and $36.84 \%)$ as percent of mean were found for magnesium and nitrogen content, signifying that there may be possibility of present non-additive gene action. Thus, heterosis breeding will be more effective. Moderate genetic advance and genetic advance in percentage of mean for phosphorus, zinc and iron indicated the importance of both additive and no additive genetic effect for controlling this character (Figure 4). So, selection of this character might be moderately effective. 


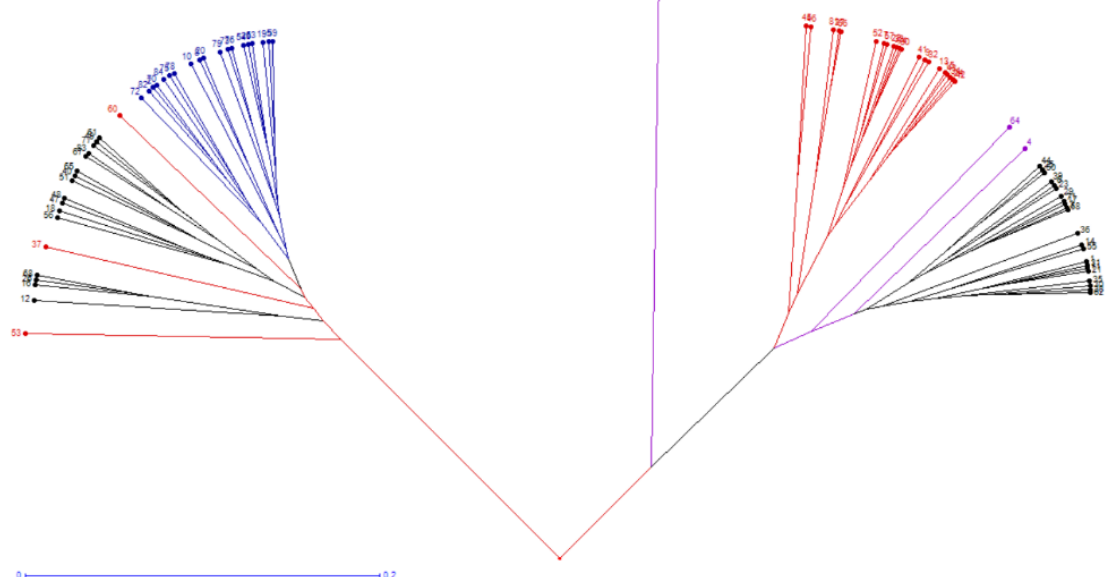

Figure 5 Neighbor-Joining Trees depicting the genetic relationships of 85 individuals from rice germplasm pool of the Department of Genetics and Plant Breeding, BSMRAU

Neighbor-joining is a bottom-up (agglomerative) clustering method for the creation of phylogenetic trees, created by Naruya Saitou and Masatoshi Nei (1987). Therefore, this grouping confirmed that the populations were genetically distant from each other as indicated. The unweighted Neighbor-Joining tree presented in Figure 5 was constructed using DARwin software 6.0 which revealed genetic relatedness among the 85 rice genotypes based on dissimilarity statistics calculated from mean data. Genotypes that are derivatives of genetically similar types clustered together. The exploited rice genotypes were clustered into three major groups underlying grain nutrient content; that was group I (36), group II (1; R079), group III (48) as shown in Figure 5. Each branch of the tree represented a single individual thus group I included $42.35 \%$, group II $1.17 \%$ and group III $56.47 \%$ of the total population indicated by the Nei's genetic distance among the populations. Thus, there are many methods to measure genetic variability while few studies have examined the relationships between them. Comparing results from different genetic diversity methods could identify the best approach for parental selection for plant breeders Barrett et al. (1998), thus increasing breeding efficiency.

Genetic variability, heat map analysis and neighbor joining clustering methods revealed that there existed considerable significant variation $(0.1 \%$ level of probability) among the genotypes for studied different grain nutrient contents and yield per hill indicated ample opportunity for screening and selecting suitable parents for biofortification program in rice breeding.

Table 3 Estimates of genetic parameters for nutrient contents of rice genotypes

\begin{tabular}{|cccccccc}
\hline Traits & $\boldsymbol{\sigma}^{\mathbf{2}}$ & $\boldsymbol{\sigma}^{2} \mathbf{g}$ & $\mathbf{P C V}$ & $\mathbf{G C V}$ & $\mathbf{h}^{2} \mathbf{b}$ & $\mathbf{G A}$ & GAPM \\
\hline $\mathbf{N}(\mathbf{m g} / \mathbf{k g})$ & 3712141.9 & 3712141.9 & 17.86 & 17.86 & 100 & 3974.77 & 36.84 \\
\hline $\mathbf{P}(\mathbf{m g} / \mathbf{k g})$ & 139359.2 & 139359.2 & 46.38 & 46.38 & 100 & 770.14 & 95.69 \\
\hline $\mathbf{K}(\mathbf{m g} / \mathbf{k g})$ & 1224730.9 & 1224730.9 & 29.13 & 29.13 & 100 & 2283.07 & 60.10 \\
\hline $\mathbf{C a}$ & 84289827.1 & 84289827.1 & 66.55 & 66.55 & 100 & 18940.3 & 137.30 \\
$\mathbf{( m g / k g )}$ & & & & & & & \\
$\mathbf{M g}$ & 192111.2 & 192111.2 & 15.77 & 15.77 & 100 & 904.22 & 32.54 \\
$\mathbf{( m g / k g )}$ & & & & & & & \\
\hline
\end{tabular}




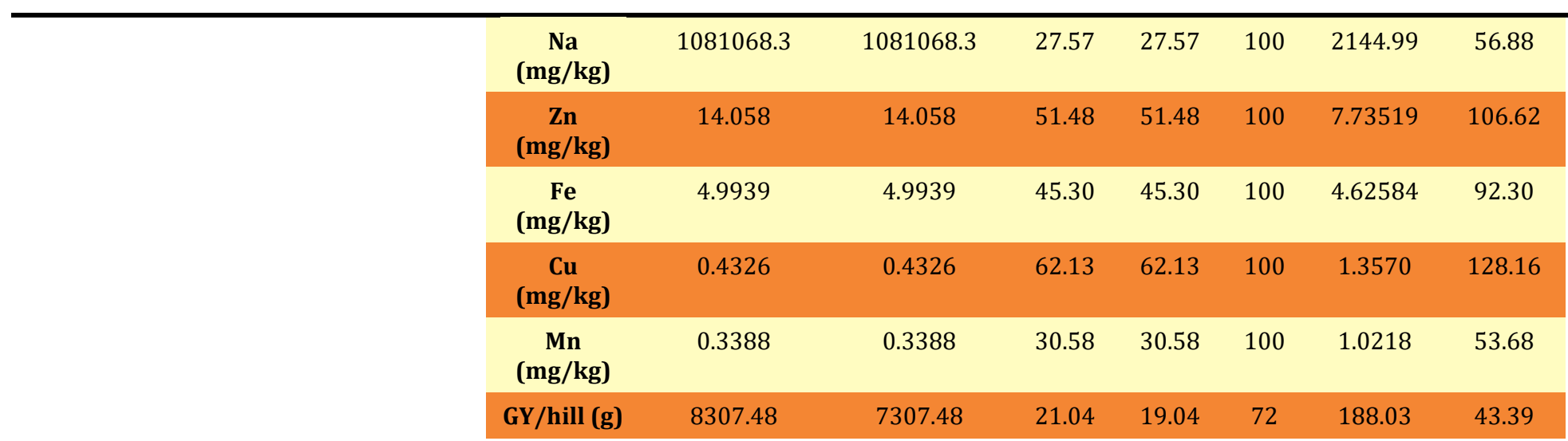

$\sigma 2 p$ : Phenotypic variance, $\sigma 2 \mathrm{~g}$ : Genotypic variance, PCV: Phenotypic coefficient of Variation, GCV: Genotypic coefficient of variation, h2b: \% heritability in broad sense, GA: Genetic advance, GAPM: Genetic advance \% mean, N: Nitrogen, P: Phosphorus, K: Potassium, Ca: Calcium, Mg: Magnesium, Na: Sodium, Zn: Zinc, Fe: Iron, Cu: Copper, Mn: Manganese, mg/kg: Parts per million, gy/hill: grain yield/ hill (g)

\section{CONCLUSION}

Among the eighty-five coastal rice genotypes, each and every genotype showed diversity in different grain nutrients content. R080 (Chinigura) was recorded for the highest content of grain P, Fe and Cu; R030 (Mota Dhan), R040 (Dudh Kalam) and R019 (Chikon Dhan) were noted for the highest $\mathrm{Ca}, \mathrm{Mg}$ and Na content, respectively. The maximum N and Zn content were observed in R029 (Dudh Kolom) and R075 (Gopal Bogh) respectively. R083 (Lal Dhan) was marked for the highest grain yield/ hill and $\mathrm{K}$ content. These genotypes can be taken into consideration for biofortification and used as parents for the improvement of rice grain quality adapted in coastal regions on the basis of specific breeding objectives. However, for biofortification breeding, a complete understanding of different grain nutrients allocation, reallocation, and remobilization within and between vegetative and reproductive tissues is lacking. Agronomic interventions alone to improve the grain nutrients have less success, but a combination of agronomic and genetic interventions approaches may likely deem bright options.

\section{CONFLICT OF INTEREST}

The Authors declare no competing financial interest

\section{ACKNOWLEDGEMENT}

The authors are grateful to the Bangabandhu Sheikh Mujibur Rahman Agricultural University Authority for providing financial support and allowing to use the laboratory and analytical facilities to conduct the experiments.

\section{REFERENCES}

Adeyeye, E. I., Arogundade L. A., Akintayo, E. T., Aisida O. A. and Alao, P. A. (2000). Calcium, zinc and phytate interrelationships in some foods of major consumption in Nigeria. Food Chemistry, 71(4), 435-441. Retrieved fromhttps://doi.org/10.1016/S0308-8146(00)00159-X

Ahuja, U., Ahuja, S. C., Thakrar, R and Singh, R. K. (2008). Rice-a nutraceutical. Asian Agri-History, $12(2)$, 93-108.

Retrieved from 
http://www.indiaenvironmentportal.org.in/files/Asian\%20Agri\%20History.pdf

Anjum, F. M., Pasha, I, Bugti, M. A. and. Butt, M. S. (2007). Mineral composition of different rice varieties and their milling fractions. Pakistan Journal of Agricultural Sciences. 44(2), 332-336. Retrieved from https://pakjas.com.pk/papers/336.pdf

Anjum, K. I., and Hossain, M. A. (2019). Nutritional and cooking properties of some rice varieties in Noakhali region of Bangladesh. Res. Agric. Livest. Fish. 6 (2): 235-243. Retrieved from https://doi.org/10.3329/ralf.v6i2.43046

Anuradha, K, Agarwal, S., Batchu, A. K, Babu, A. P, Swamy B. P. M, Longva, T., Sarla, N. (2012a) Evaluating rice germplasm for iron and zinc concentration in brown rice and seed dimensions. J Geophys Res 4:19-25. Retrieved from https://www.researchgate.net/profile/Surender-Singh-2/post/How-todo-analysis-of-the-endosperm-loading-of-iron-mineral-in-ricegenotypes/attachment/59d64e5779197b80779a7b61/AS\%3A492388305 076224\%401494405928121/download/2754-3069-1-PB.pdf

Babicki, S., Arndt, D., Marcu, A., Liang, Y., Grant, J. R., Maciejewski, A and Wishart, D. S.. (2016). Heatmapper: web-enabled heat mapping for all. Nucleic Acids Research, 44(W1), W147-W153. Retrieved from https://doi.org/10.1093/nar/gkw419

Barrett, B. A., Kidwell, K. K. and Fox, P. N. (1998). Comparison of AFLP and Pedigreebased Genetic Diversity Assessment Methods Using Wheat Cultivars from the Pacific Northwest. Crop Science, 38(5), 1271-1278. Retrieved from https://doi.org/10.2135/cropsci1998.0011183X003800050026x

Bashir, K., Takahashi, R. Nakanishi, H. and Nishizawa, N. K. (2013). The road to micronutrient biofortification of rice: progress and prospects. Frontiers in Plant Science, 4, 15. Retrieved from https://doi.org/10.3389/fpls.2013.00015

Burton, G. W and Vane, D. E. (1953). Estimating heritability in tall fescue (Festuca arundinacea) from replicated clonal material. Agronomy Journal, 45: 478481.

Retrieved from https://doi.org/10.2134/agronj1953.00021962004500100005x

Burton, G. W. (1952). Quantitative inheritance in grasses. In. Proceedings of the 6th International Grassland Congress, pp. 277-283, Ames, Iowa, USA.

Chaudhari, P. R., Tamrakar, N., Singh, L., Tandon, A. and Sharma, D. (2018). Rice nutritional and medicinal properties: A. Journal of Pharmacognosy and Phytochemistry, $\quad 7(2), \quad 150-156 . \quad$ Retrieved from https://www.phytojournal.com/archives/2018/vol7issue2/PartC/7-1256-103.pdf

Chinoy, A., Mughal, M. Z. and Padidela, R. (2019). Metabolic bone disease of prematurity: causes, recognition, prevention, treatment and long-term consequences. Archives of Disease in Childhood-Fetal and Neonatal Edition, 104(5), 560-566. Retrieved from https://doi.org/10.1136/archdischild2018-316330

Cousens, G. (2017). Why do we Need Nitrogen. Dr. Cousens'Blog. Retrieved from http://treeoflifecenterus.com/why-do-we-need-nitrogen/

Das, S. and Gulshan, J. (2017). Different forms of malnutrition among under five children in Bangladesh: a cross sectional study on prevalence and 


$\begin{array}{lccccc}\text { determinants. BMC Nutrrition, 3, } & \text { 3. } & \text { Retrieved } & \text { from } \\ \text { https://doi.org/10.1186/s40795-016-0122-2 } & & & \end{array}$

Depar, N., Rajpar, I., Memon, M. Y. and Imtiaz, M. (2011). Mineral nutrient densities in some domestic and exotic rice genotypes. Pakistan Journal of Agriculture: Agricultural Engineering, Veterinary Sciences (Pakistan). 27(2): 134-142. Retrieved from https://agris.fao.org/agrissearch/search.do?recordID=PK2012000623

Eggum, B. O. (1969). Evaluation of protein quality and the development of screening technique. In New approaches to breeding for improved plant protein. Vienna IAEA. 125-135. Retrieved from https://agris.fao.org/agrissearch/search.do?recordID=US201301163824

Eggum, B. O. (1977). Nutritional aspects of cereal protein. In A. Muhammad R. Aksel and R. C. Von Boustel, eds. Genetic diversity in plants. New York, Plenum press, 349369. Retrieved from https://doi.org/10.1007/978-1-4684-28865_32

Eggum, B. 0. (1979). The nutritional value of rice in comparison with other cereals. In proceedings, workshop on chemical aspects of rice grain quality. Los Bunos, Laguna, The Philippines IRRI, 91-111.

Gearing, M. E. (2015). Good as gold: Can golden rice and other biofortified crops prevent malnutrition? Science in the News, Harvard University.

Graham, R. D., Ross, M. W., Saunders, D. A., Ortiz- Monasterio, I., Bouis, H. E., Bonierbale, M., Haan, S de., Burgos, G., Thiele, G., Liria, R., Meisner, C. A., Beebe, S. E., Potts, M J., Kadian M., Hobbs, P. R., Gupta, R. K. and Twomlow, S. (2007). Nutritious subsistence food systems. Advances in Agronomy, 92, 174. Retrieved from https://doi.org/10.1016/S0065-2113(04)92001-9

Haas, J. D., Beard, J. L., Murray-Kolb, L. E., Del Mundo, A. M., Felix, A and Gregorio. G. B. (2005). Iron-biofortified rice improves the iron stores of nonanemic Filipino women. The Journal of Nutrition, 135(12), 2823-2830. Retrieved from https://doi.org/10.1093/jn/135.12.2823

Imtiaz, M., Khan, P., Babar, H., Depar, N., Siddiqui, S. H., Memon, M. Y., Aslam, M., Shah, K. H. and Naqvi, M. H. (2005). Mineral dietary status of existing domestic wheat genotypes. The Nucleus, 42 (3-4): 213.

Johnson, A. A., Kyriacou, B., Callahan, D. L., Carruthers, L., Stangoulis, J., Lombi, E. and Tester, M. (2011). Constitutive overexpression of the OsNAS gene family reveals single-gene strategies for effective iron-and zinc-biofortification of rice endosperm. PloS one, 6(9). Retrieved from https://doi.org/10.1371/journal.pone.0024476

Johonson, H. W., H. F. Robinson and R. E. Comostock. (1955). Genotypic and phenotypic correlations in soybeans and their implication in selection. Agronomy Journal. 47: 477- 483. Retrieved from https://doi.org/10.2134/agronj1955.00021962004700100008x

Khan, A. and Gotter, A. (2018). Hypocalcemia (Calcium Deficiency Disease). Healthline Retrieved from https://www.healthline.com/health/calciumdeficiency-disease

Mahender, A., Anandan, A., Pradhan S. K. and Pandit, E. (2016). Rice grain nutritional traits and their enhancement using relevant genes and QTLs through advanced approaches. SpringerPlus 5, 2086. Retrieved from https://doi.org/10.1186/s40064-016-3744-6 
Mamun, A. A., Sarker P. R. and Noor, M. N. A. (2019). Influence of irrigation and gypsum on wheat cultivation in saline soil. Research in Agriculture Livestock and Fisheries, 6(1): 01-10. Retrieved from https://doi.org/10.3329/ralf.v6i1.41380

Martel, J. (2017). Low Blood Sodium (Hyponatremia). Healthline. Retrieved from https://www.healthline.com/health/hyponatremia\#symptoms

Martinez, C.P., Borrero, J. , Taboada, R., Viana, J. L., Neves, P., Narvaez, L., Puldon, V., Adames A. and Varga, A. (2010). Rice cultivars with enhanced iron and zinc content to improve human nutrition. 28th International Rice Research Conference, Hanoi, Vietnam, 8-12 November 2010. OP10: Quality Grain, Health and Nutrition.

Matin, A., Siddiquee, M. A., Akther, S., Alam, M. K. and Ali, M. S. (2017). A comparative study on chemical and cooking properties of abiotic stress tolerant and other high yielding rice varieties in Bangladesh. Bangladesh Journal of Agricultural Research, 42(4): 673-679. Retrieved from https://doi.org/10.3329/bjar.v42i4.35794

Mbatchou, V. C. and Dawda, S. (2013). The nutritional composition of four rice varieties grown and used in different food preparations in Kassena-Nankana district Ghana. Int J. Res. Chem. Environ, 3, 308-315. Retrieved from https://www.researchgate.net/profile/Valentine-

Mbatchou/publication/312465733_The_nutritional_composition_of_four_r ice_varieties_grown_and_used_in_different_food_preparations_in_KassenaNankana_district/links/5ab3954d458515ecebefeb83/The-nutritionalcomposition-of-four-rice-varieties-grown-and-used-in-different-foodpreparations-in-Kassena-Nankana-district.pdf

Muhammad, Z., Farooq, A., Shaukat, A. and Tahira, I. (2012). Proximate composition and minerals profile of selected rice (Oryza sativa L.) varieties of Pakistan. Asian Journal of Chemistry, 24(1), 417-421. Retrieved from https://www.cabdirect.org/cabdirect/abstract/20113364476

Nagesh, Ravindrababu, V., Usharani, G. and Reddy, T. D. (2012). Grain iron and zinc association studies in rice (Oryza sativa L.) F1 progenies. Arch. Appl. Sci. Res. $4 \quad$ (1): 696-702. $\quad$ Retrieved from https://www.cabdirect.org/cabdirect/abstract/20123110455

Prasad, R. (2009). Ferti-fortification of grains-an easy option to alleviate malnutrition of some micronutrients in human beings. Indian Journal of Fertilisers, 5(12), 129-133. Retrieved from https://www.cabdirect.org/cabdirect/abstract/20103025275

Radcliffe, S. (2016). Mineral Deficiency. Healthline. Retrieved from https://www.healthline.com/health/mineral-deficiency\#1

Ravindra Babu, V. (2013). Importance and advantages of rice biofortification with iron and zinc. An Open Access Journal published by ICRISAT. SAT eJ.,11:1-6. Retrieved from http://citeseerx.ist.psu.edu/viewdoc/download?doi=10.1.1.670.3648\&rep $=$ rep $1 \&$ type $=$ pdf

Reddy, M., Turaidar, V., Krupa, K. N., Anantapur, R., Bharani, S. S. and Dalawai, N. (2018). Enhancement of iron and zinc in rice grain through biofortification approach. International Journal of Current Microbiology and Applied Science. 7: 628-637.

Shozib, H. B., Hossain, M. M., Jahan, S., Alam, M. S., Das, S. C., Alam, S., Amin, R. B., Hasan, M. M., Malo, R., Islam, M. R., Shekhar, H. U. and Siddiquee, M. A. (2017). 
Study of biochemical and cooking quality traits of major rice varieties of Bangladesh. Malaysian Applied Biology Journal, 46(4): 55-62. Retrieved from https://www.researchgate.net/profile/HabibulShozib/publication/322820551_STUDY_OF_BIOCHEMICAL_AND_COOKING _QUALITY_TRAITS_OF_MAJOR_RICE_VARIETIES_OF_BANGLADESH/links/5 a717e8b458515015e646e4a/STUDY-OF-BIOCHEMICAL-AND-COOKINGQUALITY-TRAITS-OF-MAJOR-RICE-VARIETIES-OF-BANGLADESH.pdf

Souci, S. W., Fuchmann, W. and Kraut, H. (1987). Food composition and nutrition tables, 3rd rev. ed. Stuttgarti, Wissen Schaftloche Verlagsgeseil schaft.

Suzuki, S., Djuangshi, N., Hyodo, K. and Soemarwoto, O. (1980). Cadmium, copper, and zinc in rice produced in Java. Archives of Environmental Contamination and Toxicology, 9(4), 437-449. Retrieved from https://doi.org/10.1007/BF01055296

Thongbam, P. D., Tarentoshi, P., Raychaudhury, M., Durai, A., Das, S. P., Ramesh, T., Patiram, K. T., Ramya, K. T., Abdul, F. R. and Ngachan, S. V. (2012). Studies on grain and food quality traits of some indigenous rice cultivars of Northeastern Hill Region of India. Journal of Agricultural Science, 4(3): 1-12. Retrieved from https://doi.org/10.5539/jas.v4n3p259

Wazir, S. M., and Ghobrial, I. (2017). Copper deficiency, a new triad: anemia, leucopenia, and myeloneuropathy. Journal of community hospital internal medicine perspectives, 7(4), 265-268. Retrieved from https://doi.org/10.1080/20009666.2017.1351289

Welch, R. M. and Graham, R. D. (1999). A new paradigm for world agriculture: meeting human needs: productive, sustainable, nutritious. Field Crops Research, 60(1-2), 1-10. Retrieved from https://doi.org/10.1016/S03784290(98)00129-4

Welch, R. M. and Graham, R. D. (2004). Breeding for micronutrients in staple food crops from a human nutrition perspective. Journal of Experimental Botany, 55(396), 353-364. Retrieved from https://doi.org/10.1093/jxb/erh064

World Food Programme. (2015). Types of malnutrition.

Zeng, Y. W., Liu, J. F., Wang, L. X., Shen, S. Q., Li, Z. C., Wang, X. K., Wen, G. S. and Yang, Z. Y. (2004). Analysis on mineral element contents in associated with varietal type in core collection of Yunnan rice. Rice Sci, 11(3), 106-112 